\title{
Syriens opløsning set fra første parket
}

\section{Bo Vestergaard Thiesen}

\section{Et øjenvidne fortæller om radikaliseringen og for- råelsen i den syriske konflikt og om en situation, der forekommer mere håbløs end nogensinde}

Min venner siger, Damaskus nu er uigenkendelig. I bydelen Shaalan, som ellers normalt er et travlt overklassekvarter med et dagligt mylder af handlende, har de dyre mærkevarebutikker slået skodderne for. Der kører pick-up trucks rundt i gaderne med Shabihas på ladet, de system-tro militser. Qassioun-bjerget med den smukke udsigt over byen er også forvandlet. Fra at være et tillokkende pusterum i de hede sommermåneder bliver bjerget nu brugt som affyringsrampe for mortergranater, hvis mål er de sydlige og østlige rebelske forstæder.

Allerede i juli sidste år talte man i Damaskus om, at regimet snart ville falde. Da forventede man, at der blot ville gå nogle få måneder. Over et år senere er den forventningsfulde ventetid om endnu en arabisk diktators fald for længst erstattet af håbløshed og et dybt splittet syrisk samfund.
Splittelsen kom i takt med, at konflikten eskalerede. Gradvist opstod der små sprækker i det ellers så fint knyttede sekteriske og politiske tæppe, som mange syrere ikke missede nogen lejlighed til at fortælle om, og tre groft skitserede grupperinger tonede frem fra godt 40 års mørke og politisk lammelse:

De afvisende som mente, at konflikten var foranlediget af udenlandske kræfter, og regimet blot beskyttede staten; De afventende - det store flertal af syrerne i midten der hverken var for eller imod regimet. Flere, jeg mødte, ændrede dog holdning, som konflikten skred frem; De radikaliserede- mennesker der trods trusler og bank, gik ind i kampen mod det brutale Assad-styre, og nogle betalte den højeste pris.

Lidt senere skal vi møde dem alle tre.

Eskaleringen af konflikten og dermed den gradvise splittelse kom i to 
afgørende ryk. Det første var i juli sidste år, hvor regimet gik meget brutalt ind i Hama. Det var i samme weekend som Breiviks massakre på Utøya. Her så man for første gang, hvilken styrke og brutalitet det syriske regime var villig til at sætte ind for at slå oprøret ned. Fra at være en konflikt, der primært centrerede sig om spredte demonstrationer og sammenstød rundt om i landet, blev konflikten nu gradvist militariseret og mere og mere internationaliseret. Set fra Damaskus var det dog, selvom situationen var eskaleret, stadig en konflikt, der foregik ude omkring i landet og ikke direkte påvirkede dagliglivet for borgerne $i$ Damaskus. Livet gik videre relativt ufortrødent.

Den anden eskalering ændrede til gengæld alt for damaskenerne. Fredag den 6. januar 2012 sprænger der en bombe foran en politistation i Midan, et meget folkeligt og farverigt sunnikvarter, hvor der løbende op til og efter har været demonstrationer imod styret. Det var første gang, at konflikten rykkede helt ind i centrum af Damaskus, og damaskenerne var nu tvunget til selv at forholde sig til konflikten.

I de kolde vintermåneder herefter ændredes stemningen gradvist $\mathrm{i}$ byen. Før virkede syrerne mere smilende og åbenbare. De var stadig gæstfrie og hjertelige, men der var nu sneget sig en alvor ind i smilene. Der er langt færre folk på gaden om aftenen. Om det var kulden eller konfliktens gradvise indtog i hovedstaden, ved jeg ikke.

Damaskus rammes, som så mange andre steder rundt om i landet, af timelange strømsvigt, stigende fødevarepriser, og der opstilles flere og flere check-points i byen bemandet af uniformløse unge mænd med AK47'er. Sikkerhedsinstitutionerne barrikaderes med sandsække og cementbølgebrydere, og damaskenerne får en forsmag på det, som har været dagligdag for flere af deres landsmænd rundt om i landet igennem længere tid.

Til trods for at konflikten nu gradvist var rykket længere ind mod byen, syntes der også at være et behov for at kunne opretholde en form for normalitet i kaos. Det kom blandt andet til udtryk på restauranterne i den gamle by, hvor fædrelandssange og sange til støtte for Assadfamilien blev spillet og sunget hver aften tilsyneladende - for en udlænding i hvert fald - uanfægtet af de tragiske begivenheder i landet.

Vi skal nu møde en af afviserne.

\section{Danseren afviser}

En torsdag aften på en restaurant $\mathrm{i}$ det kristne Bab Touma-kvarter i den gamle by sad jeg i gode venners lag. Restauranten havde som sædvanlig hyret en sanger, og der var god stemning. Folk begyndte at rejse sig fra deres borde og danse, som det hører sig til en torsdag aften. En syrisk kvinde byder mig op til dans. Vi 
danser og pludselig slår sangeren over i "Allah, Suria, Bashar u bas" (Gud, Syrien, Bashar og slut, red.). Det vælter ind på dansegulvet med syriske flag, og min dansepartner stemmer i, som var det det mest naturlige. Jeg føler mig fanget og forsøger at undgå øjenkontakt med hende og de øvrige folk på dansegulvet og vil egentlig helst bare have, at sangen stopper. Jeg siger pænt tak for dansen og går tilbage til mit bord og mine venner.

Det er ikke mit lod at dømme hende for hendes hyldest til Bashar. Der er intet, der er sort og hvidt, specielt ikke i Syrien. Med min vestlige demokratiarv in mente kommer jeg nok aldrig til helt at forstå, at visse dele af befolkningen ikke ønsker at give syrerne friheden til selv at vælge deres egen leder i frygt for, at islamister vil kaste Syrien tilbage i et middelalderligt mørke og smide den relative sekulære samfundsform på møddingen. Jeg kommer nok heller aldrig til helt at forstå, at det bedste er at bevare Bashar som den bedste af de værste onder, som flere syrere har formuleret det.

Min dansepartner og alle andre, der notorisk afviste eller lukkede øjnene for de uhyrligheder, der blev begået af det syriske regime, blev i takt med, at konflikten eskalerede, løbende fodret af styrets propagandaapparat.

Det var der flere eksempler på, som når jeg skulle på immigrationskontoret $\mathrm{og}$ have fornyet mit visum.
Her blev jeg mødt af en plakat fra indenrigsministeriet, der viste blodige sværd påtrykt henholdsvis AlJazeera, BBC og Al-Arabia'a. Flankeret af en jøde med blodige hugtænder, huggede alle tre sværd bidder af Syrien. Eller da præsidentparret Bashar og Asmaa al-Assad smilende og til stående ovationer på syrisk statsligt tv med oprullede ærmer pakkede nødhjælp til de lidende og hjemløse fra Homs i kølvandet på Bashars tæppebombning af selvsamme Homs.

Jeg behøvede ikke at se de statsejede tv stationer vise 'terrorister', der 'tilstår' et terrorangreb eller læse den ene mere horrible nyhed efter den anden på SANA (det officielle syriske nyhedsbureau online. red.). Jeg kunne få stort set de samme historier dagligt af et flertal af byens taxachauffører: 'Ma fi shi' (Der er ingen problemer her, red.), det er udenlandske terrorister, der vil Syrien det ondt.

Som da en taxachauffør, der skulle køre mig til fodbold, stolt pegede på en bus fyldt med shahbihas og sagde med knyttet næve, at de var stærke, hårde og dygtige, og der var aldrig nogen, der ville få Syrien ned med nakken.

Det syriske propagandaapparat syntes at være smurt, og mange syrere turde ikke at tro på andet end det, de blev fortalt af de statslige nyhedskanaler, ligegyldigt hvor grotesk det end måtte lyde for en udefrakommende. 
De afventende var generelt væsentlig sværere at få i tale. De ønskede mest af alt, at konflikten stoppede, og gav udtryk for, at for dem var det ligegyldigt, hvem der styrede landet, bare der var fred og normalitet. De lovpriste hverken præsidenten eller ytrede opbakning til revolutionen. De syntes på mange måder at være produktet af 40 års massiv undertrykkelse og overvågning.

Det politiske landkort er dog ikke helt klart og tydeligt. Selvom man er alawit, shia eller kristen, støtter man ikke nødvendigvis Bashar, og selvom man er sunnimuslim, er man ikke partout i opposition til regimet. Flere af de syrere, jeg lærer at kende, flytter sig også holdningsmæssigt gennem det år, jeg er i Syrien.

Sana var en af dem. En veluddannet ung kvinde i slutningen af 20'erne, jeg lærte at kende gennem fælles venner. I starten af konflikten var hun åbent i opposition til regimet, men som konflikten forrås mere og mere sideløbende med, at oppositionen militariseres og begår sekterisk vold $\bmod \mathrm{fx}$ alawitter, sagde hun til mig en dag, at hun ikke længere var sikker på, hun kunne støtte op om revolutionen, da den havde mistet sit fredelige udtryk.

Men som konflikten forværredes, blev de afventende gradvist færre. De blev nødsaget til at tage stilling. For dem blev konflikten sværere at skubbe hen som noget, de ikke behøvede at blande sig i eller forholde sig til. For som tiden gik, blev deres dagligdag mere og mere påvirket af eksempelvis de stigende fødevarepriser, afspærringerne og checkpoints, de timelange strømsvigt og mangel på gas og fyringsolie.

\section{Forråelsen}

Så var der dem, der gradvist blev radikaliseret blandt andet som konsekvens af mødet med det syriske efterretningsvæsens mørke fængselsceller. Ud af mørket kom min ven, Ali, forandret for altid.

Ali sagde altid til mig, at jeg ikke skulle stole på nogen, ikke engang ham. Jeg mødte ham første gang i juni sidste år på en bar i Bab Toumakvarteret i den gamle by. Vi blev hurtigt venner. Men i perioder var det umuligt at komme i kontakt med ham. På et tidspunkt havde han været i fængsel i syv dage for at have taget billeder af en demonstration i sit kvarter. Han ville helst ikke tale så meget om det, men når vi blev berusede, brød han af og til sammen. Han fortalte mig en sen aftentime, at de i fængslet havde tvunget ham til at være nøgen og gå ned i knæ, når de afhørte ham. De havde vanæret ham, og han ønskede kun hævn.

Igennem mit år i Damaskus gennemgår vores venskab en række udviklinger, der på mange måder følger udviklingen i landet. I perioder ønsker han ikke, at vi ses, da han er aktiv i revolutionen, og det vil kunne give mig problemer at mødes 


\section{BAGGRUND}

med ham. En dag i løbet af foråret, da vi står og laver mad, fortæller han mig, at han kraftigt overvejer at melde sig til Free Syrian Army, den frie syriske hær. Han følte ikke, han havde noget at miste i forhold til det, han kunne vinde. Da jeg forleden kommunikerede med ham på Facebook om, hvorvidt jeg måtte fortælle hans historie, skrev han, at det måtte jeg gerne, men han var ikke sikker på, han selv klarede den, da han er i store problemer i sit kvarter.

Omar, som jeg mødte sidste sommer i det interreligiøse og smukt beliggende Mar Musa kloster nord for Damaskus, hvor han sammen med sin kæreste og ven talte om revolutionens fremdrift og drømme for Syriens fremtid, klarede den ikke. Jeg mødte ham sidste gang i marts i den gamle by, hvor han kom slentrende med sin kæreste. Der var han i godt humør og på vej til USA for at gå på filmskole. To måneder senere blev han dræbt i Homs lige efter Houla-massakren i maj i år, hvor han var i gang med at filme til en dokumentarfilm.

Omar var ung, veluddannet, intelligent og havde kørt Indien tyndt på sin motorcykel. Han var en af dem, der havde idéerne og viljen til at bidrage til genopbyggelsen af det nye Syrien efter Bashar.

På vej hjem til Danmark møder jeg tilfældigt to medlemmer af the
Free Syrian Army i Amman. De sagde til mig: "This is point of no return. This is our last chance to get rid of this regime".

Efter at have boet et år i Syrien og gentagne gange oplevet, hvordan situationen på jorden kunne udvikle sig i en retning, ingen havde forudset, synes det næsten umuligt at spå om, hvilken form den syriske konflikt vil tage fremadrettet. Siden jeg forlod Damaskus i midten af maj, er det samlede dødstal eksploderet, og hundredetusinder af syrere er på flugt fra deres hjem. Udefra virker situationen mere håbløs og fastlåst end nogensinde.

Ligegyldigt hvordan det hele ender, så er der et langt og sejt oprydningsarbejde for Ali, Sana og min dansepartner fra restauranten, før det syriske tæppe er lappet helt igen. Men det er også der, håbet ligger for et nyt og bedre Syrien. Ikke hos Bashar eller, hvem der nu måtte overtage magten efter ham. Men hos det syriske folk.

Bo Vestergaard Thiesen er cand.mag. $i$ historie, mellemøststudier og arabisk sprog og projektleder ved Center for Mellemøststudier, Syddansk Universitet. Han boede og arbejdede i Damaskus fra juni 2011 til medio maj 2012.

Ali, Sana og Omars identitet er sløret. 